\title{
Reflections on the Work of the Spirit outside the Church
}

Prof. Dr. Hans S c hw a r z, Rilkestraße 44, 8411 Lappersdorf

The divine initiative is the starting point of all Christian theology if not of theology in toto. The work of God through His Spirit is not confined to the church, if we mean by church not an institution but "holy believers and sheep who hear the voice of their Shepherd" (Smalcald Articles XII). Even the insight that there is no salvation outside the church did not intend to imply that everything outside the church is a godless vacuum, void of God's presence and of the creative, sustaining, and saving power of his spirit. This will become immediately clear when we investigate the biblical use of the term spirit.

\section{The Role of the Spirit According to the Biblical Documents}

According to The Oxford English Dictionary, "The earlier English uses of the word are mainly derived from passages in the Vulgate, in which spiritus is employed to render Greek pneuma and Hebrew ruab." Thus the English use of spirit can be seen in continuity with the Greek and Hebrew usage and thus to a large extent in continuity with the biblical notion of spirit. As the Spirit of God (or the Lord), the OED defines the Spirit as "the active essence or essential power of the Deity, conceived as a creative, animating, or inspiring influence." 1

Ruab as God's empowering Spirit: Similar to Greek thought, in the Old Testament the spirit denotes the natural phenomena of wind, breath, and, more generally, that which gives life to the body (Gen. $6: 17)$. It can also be set aside as the seat of emotions and of intellectual functions (Gen. 41:8; Job 32:8). Yet in Job 32:8 we already note a very interesting remark: "But it is the spirit (ruab) in a man, the breath (neshamah) of the Almighty, that makes him understand." Not age or education leads to wisdom but God himself and his Spirit. The faculties that relate to life and its mastery are not perceived as inherent, but as given by God. Hans Walter Wolff rightly calls ruab a "theo-anthropological term." Ruab is the "wind" which proceeds from Yahweh and which will eventually return to him, constituting the breath of life: "If he should take back his spirit (ruab) to himself, and gather to himself his breath (neshamab), all flesh would perish together, and man would return to dust" (Job 34:14 f.). Often ruah, the breath of man, cannot be separated from the ruab $Y$ abweh.

1 For this and the following quote see The Oxford English Dictionary, Vol. 10, 617.

2 Hans Walter Wolff, Anthropology of the Old Testament, trans. by M. Kohl (Philadelphia: Fortress, 1974), 32. 
But the ruab Yabweb is not just the enlivening wind that becomes the breath of men. When the Psalmist says that "by the word of the Lord the heavens were made, and all their host by the breath of his mouth" (Psalm 33:6), we notice that ruab is used here synonymously with word (dabar), the same word through which in the Genesis story God created the world. Yahweh's breath is the creative power of life that determines our life span (Gen. 6:3) and tames the natural forces (Ex. 15:8). When it is imparted to people it indicates exceptional qualities. Pharaoh, for instance, looks for a man "in whom is the Spirit of God" (Gen. 41:38) so that he may tackle the problems connected with the threatening famine. To be filled with the Spirit of God can also mean to be endowed "with ability and intelligence, with knowledge and all craftmanship, to devise artistic designs, to work in gold, silver, and bronze" (Ex. 31:3 f.).

While now only isolated individuals are endowed with the Spirit of God, at the end time Yahweh will pour out his Spirit "on all flesh." Then he promises to Israel that "your sons and your daughters shall prophesy, your old men shall dream dreams, and your young men shall see visions" (Joel 2:28). Similarly we hear in Ez. 36:26 f.: "A new heart I will give you, and a new spirit I will put within you; and I will take out of your flesh the heart of stone and give you a heart of flesh. And I will put my spirit within you, and cause you to walk in my statutes and be careful to observe my ordinances."

Though humanity is not without spirit, only the Spirit of God leads to right living and fulfillment of the will of God. The Psalmist attests the same fact when he prays: "Create in me a clean heart, O God, and put a new and right spirit within me. Cast me not away from thy presence, and take not thy Holy Spirit from me. Restore to me the joy of thy salvation, and uphold me with a willing spirit" (Ps. 51:10 ff.). Life, power, and freedom are not taken for granted, but are seen as related to God. He gives his Spirit and we are vigorous, wise, and renewed. He takes his Spirit away and we are confused, sick, and like those in the pit. Humanity's ruab (spirit) can only be properly understood out of God's communion with us. Most Old Testament texts that mention the Spirit of God show God and humanity in a dynamic relationship. "That man is living, desires the good and acts as authorized being - none of this proceeds from man himself." 3 Our full humanity can be developed only in relationship with God. While it will find its fulfillment on a universal scale in the eschaton, it is anticipated to various degrees already now, whether within the Israelite covenant community or outside of it, since God's activity has created and sustains his whole creation.

3 Ibid., 39. 
The increasing independence of ruab according to the intertestamental writings: Contrary to the Old Testament, in Judaism the distinction evolved between spirit and body so that body was considered to be of earthly derivation, while the spirit connects humanity with the heavenly dimension. Consequently, there developed the notion of immortality of the soul and of preexistence. Rabbi Simai (c. 210), for instance, taught:

All creatures that have been created from heaven (i. e. from heavenly substances), their soul and body is from heaven; an all creatures that have been created from the earth (from earthly substances) their body and soul is from the earth. Therefore, when a man keeps the tora and the will of his father in heaven, see, he is like the creatures from above. ${ }^{4}$

Interesting for us is not so much the notion of a dual origin of body and soul that is expressed by Rabbi Simai, but the fact that humanity is seen in the twofold relationship, on the one hand connected with and rooted in this world, and at the same time related to God. If humanity lives in conformity with God's will, it evidently must live according to its heavenly destiny.

The writers of the Old Testament apocrypha and pseudepigrapha understood ever more clearly that the human spirit is moulded by outside sources, most prominently by the Spirit of God. Though the Spirit of God is especially the spirit of prophecy through which one prophesies and sees hidden things (Sir. 48:12 f.), we also hear about the spirit of understanding (Sir. 39:6; Test. Levi 2:3), and of wisdom (Wis. 9:17). The Spirit of God therefore enables one to discern and to live in accordance with the will of God. But the Spirit also has a cosmic function. It is the instrument of divine creation when God sent forth his Spirit and built the world (Judith 16:14).

Judaic reflection on the role of the Spirit attributes to it a growing measure of autonomy. Strack-Billerbeck remarked that often the Holy Spirit that speaks through Scripture is personified by saying that he speaks, calls, or proclaims. ${ }^{5}$ This is done especially in cases when one wanted to explain one scripture passage by referring to another passage. The Holy Spirit also seems to assume God's partnership by performing the same function that had been attributed to God's justice and compassion. Yet the Spirit does not become an independent actor but rather a divine reality that meets humanity and elicits its response.

The life-giving power of the pneuma according to the New Testament: When we now consult the New Testament, we simply want to mention those lines that have bearing on our understanding of the work of the Spirit in the world. But before doing so, we should at least allude

\footnotetext{
4 According to Hermann L. Strack und Paul Billerbeck, Kommentar zum Neucn Testament aus Talmud und Midrasch, Vol. 2 (Munich: C. H. Bed, 1924), 430.

5 Ibid., 134.
} 
to gnostic literature, since there the spirit is a dominant category. The most important feature for us in gnosticism is the break of the unity between God and the world. Since power is now thought of as substance, the life-giving power of God was eventually conceived of as being held captive in the body. Thus humanity had no longer a twofold relationship, but a dual nature. God, being spiritual, bound his spiritual nature to matter in creation from whence this spiritual nature wants to be redeemed. Since God is Spirit, he is not the actual creator of matter but its life-empowering force. Therefore, matter itself is not redeemable. We are redeemed from our bodies by returning to our spiritual existence with God.

When we hear Jesus saying in Mt. 12:28: "But if it is by the Spirit of God that I cast out demons, then the kingdom of God has come upon you," we notice that the Old Testament notion has been retained that the Spirit of God has the power to perform unusual deeds. Also the filling of the people with the Spirit as the eschatological sign is mentioned in the gospels (Mk. 1:8). The prime example of this, of course, is Jesus himself in his baptism (Mk. 1:10 ff.). Similar to God creating in the beginning the world through his Spirit, he now creates the first form of the new creation through his pneuma (Mt. 1:18; Lk. 1:35).

While Matthew and Mark mentioned the Spirit of God relatively seldom, the story is different with Luke. The presence of the Spirit characterizes the time of the church. At Pentecost the disciples were filled with the Holy Spirit (Acts 2:4) and everyone who is baptized into the Christian community will likewise receive the Holy Spirit.

For John, the Spirit assumes a more cosmological function, when the Spirit is seen as a sphere that stands in antithesis to the flesh. So John talks on the one hand about the Spirit, from above, and God, and on the other hand, about flesh, from below, the devil, and the cosmos. "God is Spirit, and those who worship him must worship in spirit and truth" (John 4:24), do we hear Jesus say. The Spirit that is identified with God and with Christ is the life-empowering factor, since "it is the spirit that gives life, the flesh is of no avail; the words that I have spoken to you are spirit and life" (John 6:63). Of course, the spirit is not a natural human option, since "that which is born of the flesh is flesh, and that which is born of the Spirit is Spirit" (John 3:6). True life can be found only in the sphere of the Spirit, and this means with God. As the paraclete sayings indicate, the Counselor will be "the Spirit of truth, whom the world cannot receive" (John 14:17). Though John does not compromise the insight that we cannot obtain true knowledge on our own, he also shows that God has brought truth to us when the "word became flesh" (John 1:14). Thus those in the world do not live in a godless vacuum. Through Christ's coming everyone has the possibility of a rebirth (John 3:7) and of living according to the Spirit. Unlike 
the Old Testament that spans many centuries, John does not reflect upon how this enlivening Spirit is also active in places where he is not explicitly recognized. The case is similar with Paul.

As in John we notice that Paul identifies the Lord (Jesus Christ) with the Spirit when he writes: "Now the Lord is the Spirit and where the Spirit of the Lord is, there is freedom" (2 Cor. 3:17). Unlike in gnostic thought the spiritual and the physical are not opposites. Paul confesses that "it is sown a physical body, it is raised a spiritual body" (1 Cor. 15:44). The reason for the confidence that the physical will be transformed into the spiritual lies in the fact that the first Adam became a living being, but "the last Adam became a life-giving spirit" (1 Cor. $15: 45)$. The physical therefore obtains its direction from the spiritual, because of Christ and his resurrection. The transformation into the Spirit or into being in Christ is not just a future event. Already now God has given us the Spirit as a guarantee, or rather down-payment (2 Cor. 5:5). Christians are reminded to "walk not according to the flesh but according to the Spirit" (Rom. 8:4), reminding us that the Spirit is the norm of life and expresses the will of God. Since even Christians have to be reminded of the new life in Christ, we are not surprised that nonChristians have even less a perception of their relationship to God. But Paul does not simply excuse them. On the contrary, he states: "Ever since the creation of the world his invisible nature, namely his eternal power and deity, has been clearly perceived in the things that have been made. So they are without excuse. ... but they became futile in their thinking and their senseless minds were darkend" (Rom. 1:20 f.). The presence of God and of his Spirit in the world is not to be disputed. But this does not imply that everyone perceives him as being active in the world. God can only be grasped where through his Spirit he made himself graspable, in his historic manifestation in Jesus Christ. From there the Spirit's life sustaining activity in the world needs to be affirmed and clarified. This seems to be the line of reasoning that the early church pursued.

\section{The Spirit Outside the Church According to the Early Church}

In the Old Testament the "Holy Spirit" is not conceived of as an independent entity, but as the Spirit of God. The same is true for the New Testament. In the latter, however, the relationship is complicated by the emergence of Jesus Christ. Since Jesus is also not conceived of as an entity independent of God, but is referred to as the Son of God (the Father) the question emerges, how Jesus Christ and the Spirit are related to each other.

Clarifying the relationship between God, Spirit, and Jesus Christ, the church noticed that God through his Spirit incarnated his Son, that 
the Spirit. Yet the relationship goes further. In 2 Clem. 9:5, for instance, we hear that "Christ, the Lord who saved us, though he was originally spirit, became flesh and so called us." This means that Jesus was spirit before he became flesh. Another very interesting passage indicating a similar line of reflection is found in The Shepherd:

The Holy Spirit which pre-exists, which created all creation, did God make to $\mathrm{d}$ well in the flesh which he willed. Therefore this flesh, in which the Holy Spirit $\mathrm{dwelled}$, served the Spirit well, waling in holiness and purity, and did not in any way defile the spirit. When, therefore, it had lived nobly and purely, and had laboured with the Spirit, and worked with it in every deed, behaving with power and bravery, he chose it as companion with the Holy Spirit; for the conduct of this flesh pleased him, because it was not defiled while it was bearing the Holy Spirit on earth (Herm. Sim. V, 6:5 f.).

We note in this passage the emphasis on the intimate unity of Spirit and the Son, even referring to them in the pre-existent state with the same term, Holy Spirit, and stating that through the Holy Spirit all creation was made. ${ }^{6}$ Before Jesus was incarnate, he was in the state of divine power in glory; he was Holy Spirit and then assumed flesh.

Bishop Theophilus of Antioch (c. 169) in his three books to Autolycus picks up this trend of thought and develops it further when he says:

$\mathrm{He}$ (God) used this Logos as his servant in the things created by him, and through him made all things (cf. John 1:3). He is called Beginning because he leads and dominates everything fashioned through Him. It was he, Spirit of God (Gen $1: 2$ ) and Beginning (Gen. 1:1) and Sophia (Prov. 8:22) and Power of the Most High (Luke 1:35), who came down into the prophets and spoke through them about the creation of the world and all the rest... In order for the real God to be known through his works, and to show that by his Logos God made heaven and earth and what is in them, he said: 'In the Beginning, God made heaven and earth."

Two items are noteworthy here:

1. God is present in the logos as the God who discloses himself.

2. As the connection between Prov. 8:22 and John 1:2 shows, the essence of the logos is the pneuma or Spirit. On another occasion Theophilus connects the logos with sophia and relates it to the pneuma when he says:

$\mathrm{He}$ is God who heals and gives life through Logos and Sophia. God made everything through Logos and Sophia for by his Logos the heavens were made firm and by his Spirit all their power (Psalm 32:6). His Sophia is most powerful: God by Sophia founded the earth; he prepared the heavens by intelligence; by knowledge the abysses were broken up and the clouds poured forth dews (Prov. 3:19 f.). ${ }^{8}$

- For the discussion of this passage cf. Reinhold Seeberg, Lebrbuch der Dogmengeschichte, Vol. 1 (Darmstadt: Wissenschaftliche Buchgesellschaft, 1965), $127 \mathrm{f}$.

7 Theophilus of Antioch, Ad Autolycum, text and trans. by Robert M. Grant (Oxford: Clarendon, 1970), $39 \mathrm{ff}$. (2:10).

8 Ibid., 11 (1:7). 
In God pneuma and logos are seen as an inseparable unity. We also noice that pneuma and sophia are interchangeable. With these descriptions nothing is said, however, about the internal relationship of the Deity. Primary emphasis is given to God's self-disclosure or his external work. While the creaturely character of the pneuma is not denied, Theophilus endeavors to show that in the pneuma God himself is active. Thus the pneuma, the life-creating power of creation, was enfleshed in the historical reality of Jesus. ${ }^{9}$

Irenaeus of Lyons advanced the idea of the intimate relationship between God, Son, and Spirit even further, and, what is most interesting for us, in explicit contradistinction to gnostic thought. In opposition to gnostic speculations of numbers and systems Ireaneus claims: God does not "derive His being from things made, but things made from God. For all things originate frome one and the same God." ${ }^{10}$ God is personal and at the same time the supreme, almighty and powerful creator of all things. "One only God, to the exclusion of all others, formed all things by his word, whether visible or invisible, heavenly or earthly, in the water or under the earth." Against gnostic attempts to divide the Deity into logos, the principle of thought, and mind, the active intention, Irenaeus affirms the indivisible unity of God. He is "all mind, all reason, all active spirit, all light, and always exists one and the same," Irenaeus gathers from the Scriptures. ${ }^{12}$ "But God being all Mind, and all Logos, both speaks exactly what $\mathrm{He}$ thinks and thinks exactly what $\mathrm{He}$ speaks." 13 Thus God is not a compound being, but a being in unity of Father, Son, and Spirit. Irenaeus agrees with the Scriptures that God "By His Word and Spirit, makes and disposes and governs all things, and commands all things into existence." 14 Affirming that God needs no intermediaries to create the world, Irenaeus says that God's "offspring and His similitude do minister to Him in every respect; that is, the Son and the Holy Spirit, the Word and Wisdom; whom all the angels serve, and to whom they are subject." ${ }^{15}$ Son and Spirit are seen as a unity, though they are not undistinguished.

The Sprit is even called the similitude of God, evidently in reference to his spiritual being. In the same section Irenaeus also remarks that contrary to Jewish thought the Father cannot be known without the Word, i. e. without the Son. This would mean that the working of the Spirit outside the church cannot be discerned without reference to

- For more extensive comments on Theophilus cf. Theodor Rüsch, Die Entstehung der Lebre vom Heiligen Geist bei Ignatius von Antiochia, Theophilus von Antiochia und Irenäus von Lyon (Zürich: Zwingli, 1952), $89 \mathrm{f}$.

10 Irenaeus, Against Heresies (II, 25:1), in The Ante-Nicene Fathers, ed. by Alexander Roberts and James Donaldson, Vol. 1 (Grand Rapids, MI: Wm. B. Eerdmans, 1950), 396.

12 Ibid., 400 (II, 28:4).

14 Ibid., 347 (I, 22:1).
13 Ibid., 400 (II, 28:5).
15 lbid., 470 (IV, 7:4).
11 Ibid., 398 (II, 27:2). 
God's self-disclosure in his Son. Irenaeus makes it further clear that those things which are of corruptible, earthly, transitory, and compound nature cannot be images of those things that are spiritual, "unless these very things themselves be allowed to be compounded, limited in space, and of a definite shape."16 In other words, there is no natural knowledge of God possible, unless God takes the initiative and makes himself known within space and time. "For in no other way could we have learned the things of God, unless our Master, existing as the Word, had become man." 17 Yet the communion of God with humanity and the imparting of God to humanity are not simply achieved through the incarnational process but essentially through the pouring out of "the Spirit of the Father."18 We notice again that logos and pneuma work hand in hand.

Since Irenaeus wrote his book to refute gnostic and other heresies, it would have been counterproductive for him to affirm the present work of the logos or the pneuma outside the church. His statements, however, do not preclude such activity. They make clear that if such activity were to be admitted at all its discernment could not be achieved through the natural faculties of humanity but through the work of the triune God. Yet both Theophilus and Irenaeus understood it to be a matter of fact that God through his logos and his pneuma had created the world. Thus the world owes its existence to the triune God.

The near homoousia of the Spirit at Nicaea and Constantinople: Athanasius intensifies the notion of the intimate interrelatedness of Father, Son, and Spirit; "As the Son is in the Spirit as in his own image, so also the Father is in the Son." 19 He then relates the salvational process to all three by noting: "There is one sanctification which is derived from the Father, through the Son, in the Holy Spirit." ${ }^{20}$ Yet there is a clear procession, since the Son as Son is sent forth from the Father, and the Son in turn sends the Spirit. Since the Son pertains to the essence of the Father and the spirit to the essence of the Son, there is no gradation in perfection. All three are one.

We also hear that the Spirit is involved in the incarnational process, for Athanasius claims: "When the Word visited the Holy Virgin Mary, the Spirit came to her with him, and the Word in the Spirit moulded the body and conformed it to himself; desiring to join and present all creation to the Father through himself." ${ }^{21}$ It is significant

\footnotetext{
16 Ibid., 368 (II, 7:6).

17 Ibid., $526(\mathrm{~V}, 1: 1)$.

18 Ibid., 527 (V, $1: 1)$.

19 Ad Serapion (1:20), in The Letters by Athanasius Concerning the Holy Spirit, trans. with intro. notes by C. R. B. Shapland (New York: Philosophical Library, 1951), 115.

20 Ibid., 120 (1:21).

21 Ibid., 145 f. (1:31).
} 
that creation leads to incarnation. As the Spirit has been involved in salvation, he has also been active in creation. Athanasius assures us: "The Father creates all things through the Word in the Spirit; for where the Word is, there is the Spirit also, and the things which are created have their vital strength out of the Spirit from the Word." ${ }^{22}$ In analogy to Old Testament thought, creation is not seen as self-subsistent, but as deriving its vital strength from God's Spirit. The Spirit also seems to be with his creation, since "the Father, through the Word, in the Holy Spirit, creates and renews all things." 23

The phrase that the Spirit creates and renews is echoed in many other writers, such as Basil, Didymus, and Cyril of Alexandria. ${ }^{24}$ But Athanasius goes one step further, saying that in the Spirit through the Word, the Father perfects and renews all things. ${ }^{25}$ Athanasius thinks of creation and sanctification as a single work. The creative action of the Spirit is thus seen in the context of God's sanctifying operation. As Shapland says in his introduction to Athanasius' letter to Bishop Serapion of Thmuis: According to Athanasius "God cannot create without imparting to His creatures something of His own character; and the continuance of His works is only secured by His presence within them." ${ }^{26}$ Creation leads to God's preservation and finally to redemption, or, as Gregory of Nyssa so well remarked: "We should be justified in calling all that Nature which came into existence by creation a movement of Will, an impulse of Design, a transmission of Power, beginning from the Father, advancing through the Son, and completed in the Holy Spirit."27

The culmination of these reflections comes in 381 , at the Council of Constantinople, when the Creed of Nicaea was modified especially to re-emphasize the function of the Spirit. Now it is stated that the Spirit was involved in the incarnational process by saying that Jesus Christ "was incarnate from the Holy Spirit and the Virgin Mary." Then the Holy Spirit is referred to as "the Lord and life-giver, Who proceeds from the Father, who with the Father and the Son is together worshipped and together glorified, Who spoke through the prophets." Most of these insertions reflect scriptural precedents. Incarnate from the Holy Spirit in Luke 1:35, the Holy Spirit as Lord in 2 Cor. 3:17, as life-giver in John 6:63, and as proceeding from the Father in John

\footnotetext{
22 Ibid., $174(3: 5)$.

Ibid., 127 (1:24).

Ibid., n. 8, 127.

25 Ibid., 37, in Shapland's introductory remarks.

28 Ibid.

27 Gregory of Nyssa, "On the Holy Spirit. Against the Followers of Macedonius," in $A$ Select Library of the Nicene and Post-Nicene Fathers of the Christian Church, Second Series, ed. by Philip Schaff and Henry Wace, Vol. 1 (Grand Rapids, MI: Wm. B. Eerdmans, 1954), 320.
} 
15:26. The phrase "who with the Father and the Son is together worshipped and together glorified." however, is not expressly mentioned in Scripture. We find a resemblance of this phrase when Athanasius says that the Spirit "is glorified with the Father and the Son." ${ }^{28}$ Also, a letter of Basil states that "the Son is confessed to be of one substance with the Father, and the Holy Ghost is ranked and worshipped as of equal honor." ${ }^{29}$ Though the Creed of Constantinople essentially claims the homoousia of the Spirit, it scrupulously avoids the term so as not to alienate those who did not want to elevate the Spirit to the status of God. ${ }^{30}$

\section{The Function of the Spirit Outside the Church According to the Reformers and Contemporary Theologians}

We have noticed that the Spirit is primarily involved at three points, 1) as God's life-giving power of creation, 2) in God's incarnation in Jesus Christ, and 3) in God's vivifying and sanctifying work in the church. While the last two are in one way or another related to the work of the Spirit in the church, the first one seems to be more encompassing. This is also the line of thought pursued in the Reformation period.

The work of the Spirit in the natural orders according to the reformers: According to the reformers the dominant work of the Spirit was in the salvational process. But especially for Luther it was clear that God was also active in history. And how else would he be active in history than through his Spirit. For instance, Luther says: "Through Baal and godless prophets and tyrants God has done and continues to do many good things, since the office which they have is not theirs, but it is God's. Therefore, it is efficacious ever so much in godless persons through the merit of the Holy Spirit."31 On another occasion, he states: "If a prince governs well, it is not innate nor is it learned only through books, but it is learned through the inspiration of the Holy Spirit with experience." 32 This means that everything that occurs in conformity with God's rule is done through the discerning and guiding power of the Holy Spirit. Luther learned from the Old Testament that God is not confined to Israel in his activities. His conviction that God also works

28 Ad Serapion, 142 (1:31).

29 Basil the Great, Letters (90:2), in A Select Library of the Nicene and Post-Nicene Fathers of the Christian Church. Second Series, Vol. 8, 176.

so Cf. the extensive comments by J. N. D. Kelly, Early Christian Creeds (3rd ed.; London: Longman, 1972), $342 \mathrm{f}$.

31 WA 39 II, 198, 21-24, (Die Promotionsdisputation von Heinrich Schmedenstede; 1542).

32 WA 40 III, 209, $5 \mathrm{f}$., (In XV Psalmos graduum: 1532/33), in his comments on Ps. 127:1. 
outside the realm of salvation is especially well expressed in his notion of the Wundermänner who are sent by God at crucial points to change the course of world history and avert evil. ${ }^{33}$ The Holy Spirit is at work in salvation history as well as in political history, in the church as well as in the profane godless world. ${ }^{34}$

Luther notices that the Spirit does not just affect historical constellations. The spirit is also active in the living together of people and in natural (biological) functions. Thus Luther states:

Spirit is everything that is worked in us through the Spirit. Flesh is whatever is done in us according to the flesh outside the Spirit. Therefore all the functions of the Christians, such as loving the wife, procreating children, governing the family, honoring the parents, being obedient to the magistrate, etc., which in themselves are secular and of the flesh, are fruits of the Spirit. Blind people do not distinguish the things that are of the good creatures of God from vices. ${ }^{35}$

Luther shows here that the Spirit is the force in all of life that urges us to live in a way that insures harmony, peace and the preservation of humanity. What we often take for granted and assume to result from our own ingenuity, the natural law, human reason, or even enlightened self-interest, Luther understands as the work of the Holy Spirit.

If it is true, as Scriptures say and the early church attested, that the Spirit is God's creative and enlivening Spirit, we need not be surprised by Luther's conclusions. He recognized that without the Spirit our world is threatened by chaos and destruction. But he did not assume that everyone is automatically aware of the workings of the Spirit. Neither did he reflect on how one could become aware of them, except to say that some are blind to the Spirit's workings. We may conclude that the Spirit is active in our world, an activity which can be acknowledged and reinforced through our own actions unless we blind ourselves to his works (cf. Rom. 1:20).

With reference to Gen. 1:2, Calvin holds similar views to Luther's when he says:

That the beauty of the universe (which we now perceive) owes its strength and preservation to the power of the Spirit. ... For it is the Spirit, who, everywhere diffused, sustains all things, causes them to grow, and quickens them in

33 Gunnar Hillerdal, "Luthers Geschichtsauffassung," in Studia Theologica, Vol. 7, Fasc. 1 (1953), esp. 42-53, where he says that Luther's doctrine of the Wundermänner is one of the most important parts of his understanding of history.

34 So rightly Paul Althaus, The Theology of Martin Luther, trans. by R. C. Schultz (Philadelphia: Fortress, 1966), 440. It is noteworthy that in the index of the English translation of Althaus references to the Holy Spirit are missing, while in the German original there are several significant references given that especially deal with Luther's understanding of the work of the Spirit in the political realm.

35 WA $40 \mathrm{I}, 348,15-20$, (In epistolam S. Pauli ad Galatas Commentarius 1531), in his comments on Gal. 3:3. 
heaven and in earth. ... In transfusing into all things his energy, and breathing into them the essence, life, and movement, he is indeed plainly divine. ${ }^{36}$

Calvin recognizes the Spirit as the life-giving and life-preserving power of God. It is significant that Calvin does not see this function of the Spirit as independent from the soteriological activity of the Spirit. In the paragraph following the above mentioned statement, Calvin also asserts that the Spirit is the author of generation and preservation as well as of regeneration towards future immortality. Creation and new creation are rightly seen as evolving from each other through the power of God's Spirit.

When we briefly survey the Lutheran confessional documents, we notice a remarkable silence concerning the work of the Holy Spirit in and through creation. If we remember what Luther had said, we can, of course, understand that the assertion in the Augsburg Confession "that lawful civil ordinances are good works of God" (CA XVI) implies "through the power of the Spirit." But this is not said there explicitly. In article XVIII of the Augsburg Confession, on Free Will, we could again expect discussion of the work of the Spirit. But on the contrary, we only find there the assertion that we do not "have the power, without the Holy Spirit, to attain the righteousness of God - that is, spiritual righteousness." While this statement is certainly true it becomes lopsided if not wrong if it is isolated and absolutized, as has happened quite often in Lutheranism. The Holy Spirit does not just work towards new life as spiritual righteousness but also towards creation and preservation of life in a much more comprehensive sense.

This failure to mention the Spirit's creative activity outside the salvational process is symptomatic of the Lutheran Confessional documents. It reflects their narrow reforming intent to right certain abuses in the church - at that time primarily the idea that one could obtain salvation through one's own efforts. But because of their narrow basis they cannot serve to refound the church and were not intended for that purpose. This truncated conception of the work of the Spirit is still seen in Regin Prenter's noteworthy work Spiritus Creator. While he emphasizes the life-creating and life-saving work of the Spirit, Prenter falls prey to the salvational preoccupation when he says: "Sanctification is simply another expression for the creative work of the Spirit." 37 Sanctification is certainly an important work of the Spirit. But it is not synonymous with the creative and preserving activity of the Spirit which is also conducted outside the church, i. e. where sanctification does not take place.

so John Calvin, Institutes of the Christian Religion, ed. by J. T. McNeill, trans. by. F. L. Battles, Vol. 1 (Philadelphia: Westminster, 1960), 138 (I, 13:14).

37 Cf. Regin Prenter, Spiritus Creator, trans. by J. M. Jensen (Philadelphia: Muhlenberg, 1953), 192; quotation from 186. 
The Work of the Holy Spirit according to Contemporary Theology: When we finally briefly survey the present theological scene, we notice that systematic theologians at least devote ample space in their writings to the Holy Spirit. In volume III of his Systematic Theology, Paul Tillich offers an extensive treatment of the Holy Spirit. He illuminates the function of the Spirit in reference to the ambiguities of life. The Divine Spirit is manifested in the human Spirit primarily through faith and love. The Spirit creates a Spiritual Community through the new being in Christ. The Spiritual Community has an impact on culture by opening the avenue of the Spiritual Presence. While the secular culture as such is not Spiritual, Tillich affirms "that it is open to the impact of the Spirit even without the mediation of the church." ${ }^{38}$ Yet Tillich also affirms "convergence of the holy and the secular," since the secular stands under the rule of all life, transcending itself in vertical line. In other words, the world is not its own goal. It exists, whether it acknowledges it or not, toward God. The Spiritual Presence also creates a theonomous culture and a theonomous reality, reestablishing the essential unity of morality, culture, and religion that was destroyed under the conditions of existence. ${ }^{39}$ Though Tillich recognizes the active presence of the Spirit in morality and culture, it is significant that in contrast to Scripture he does not adknowledge the activity of the Spirit to be operative beyond humanity. He only affirms that the impact of the Spiritual Presence on the human spirit implies an impact on the psyche, "the cells, and the physical elements which constitute man." 40 We might not be wrong to assume that a decisive impulse for seeing the work of the Spirit restricted to the human sphere was the preoccupation with salvation in the German Lutheranism out of which Tillich came.

Pierre Teilhard de Chardin in his evolutionary concept of life has overcome this anthropocentrism with regard to the activity of the Holy Spirit. In The Divine Milieu Teilhard states: "The same beam of light which Christian spirituality, rightly and fully understood, directs upon the Cross to humanise it (without veiling it) is reflected on matter so as to spiritualise it." 41 There is a general drift of matter toward Spirit and one day "the whole divinisable substance of matter will have passed into the souls of men; all the chosen dynamisms will have been recuperated; and then our world will be ready for Parousia." 42 The goal

38 Paul Tillich, Systematic Theology, Vol. 3: Life and the Spirit. History and the Kingdom of God (Chicago: University, 1963), 247. - ${ }^{39}$ Ibid., 266.

40 Ibid., 276. It is also interesting in this context that Helmut Thielicke, Der evangelische Glaube, Vol. 3: Theologie des Geistes (Tübingen: J. C. B. Mohr, 1978), rejects Pannenberg's attempt to emphasize the cosmological function of the Spirit and instead defines the Spirit "as the ungraspable power of making things present" (7). Thielicke assumes that in so doing he retains a biblical approach to the Spirit.

41 Pierre Teilhard de Chardin, The Divine Milieu, An Essay on the Interior Life (New York: Harper, 1960), 81. - ${ }^{42}$ Ibid., 86. 
of the creative process, with the Spirit as the creative principle, is the spiritualization and divinization of matter, humanity included. One day, through divine action, the world will be received into the Christosphere. In his deliberations Teilhard arrives at a new definiton of the Spirit: Spirit is no longer independent of matter, or in opposition to it, but laboriously emerging from it under the attraction of God by the way of synthesis and centration. ${ }^{43}$ The Spirit is the creative and life-giving power of God. It is the interior side of all life and of all being. It elevates matter and moves it towards God. It becomes clear that for Teilhard creation is only the starting point for the whole divinization process. While we must be impressed with his recognition of the allencompassing work of the Spirit, we may also wonder about the facility with which everything and everyone participates in the evolutionary process. The resistance to the Spirit by the forces and powers of darkness that the New Testament sources intimate does not seem to be taken sufficiently into account.

Among other contemporary theologians Wolfhart Pannenberg, especially, reflects on the function of the Spirit and, in analogy to Old Testament insights, he regards the Spirit "as the marvelous depth of life out of which all life originates." 44 The breath of life that permeates all life is at the same time the fount of truth and freedom. The Spirit enlivens and thereby sets us free and shows us the truth of life. Pannenberg sees the Spirit active in the self-transcendence of life. This selftranscendence is at the same time an activity of the living organism (our own spirit) and the activity of a power which lifts the living organism beyond its limits and grants it life through this activity. ${ }^{45}$ Thus the work of the Spirit is not confined to engagement with the human consciousness.

Since we humans continuously assess our environment in order to change it, and to live in it, we need a basis beyond ourselves from which to assess our approach to life. This point, Pannenberg concluded, can only be found in that which brings all reality together, i. e. in the Spirit. The Spirit is therefore also the basis for trust, hope, and love. Yet Pannenberg realizes that we are not continuously connected with the power of the Spirit. We need the Christian message to tell us about a new life in which we are no longer subjected to the ambiguities and the limits of this life. In other words, we depend on a new life for our striving to receive eternal validity. "But the Spirit of this new life, which fills the community of faith, is none other than the one who animates all life." 46

43 Pierre Teilhard de Chardin, The Future of Man, trans. by N. Denny (New York: Harper, 1964), 93. - ${ }^{44}$ Wolfhart Pannenberg, Gegenwart Gottes. Predigten (Munich: Claudius, 1973), 106, in a sermon on John 4:19-24. - ${ }^{45} \mathrm{Cf}$. Wolfhart Pannenberg, "The Spirit of Life," in Faith and Reality, trans. by J. Maxwell (Philadelphia: Westminster, 1977), 35.

46 Ibid., 38 (own trans.). 
We could continue our survey of contemporary theology for many more pages, but we want to stop here. In the face of the history of Christian thought that we traced in regard to the work of the Spirit outside the church we come to the following conclusions:

1. The Church was right when, under the impression of the Christ event, it emphasized that the Spirit makes Christ present to faith. In other words, the sphere of the Spirit's operation is foremost conterminous with the area of the specifically Christian faith.

2. The church also realized that salvation history is the key to and the center of a much larger history, the history of humanity and of nature.

3. In using initially the term logos and Spirit in parallel and interchangably when speaking about God's relation to the world, the church asserted that God's creative and preserving power, active in all creation, is undivided. To emphasize that God is active through his same power in history in general and in salvation history, it is proper to speak of the creative and sustaining presence of the Spirit in all the world. ${ }^{47}$

4. Since the self-disclosive history of God culminates within salvation history in the Christ event, the church never endowed the presence of the Spirit in the world (i. e. outside Christ) with revelatory significance. Moreover, only because our finite spirit is touched by the infinite are we capable of recognizing God's self-disclosure in Jesus Christ.

5. Human reason, discernment between right and wrong, and culture as self-expression of the humanum are not self-originated results of a natural human faculty. They stem from the work of the Spirit in the world (e.g. kingdom to the left). Therefore unreason, pursuit of injustice instead of right, and culture as human depravity are signs of the denial of the metaphysical basis of this world and manifestations of the anti-Christ. Yet the very fact that the Spirit of God sustains even a fallen world and that he erects the victory sign of the cross within it shows that God in his compassion does not condone the world's depravity but opens for it the future of a new creation.

6. If we perceive the Spirit as being active only in the church, we fall prey to a Manichean dualism that surrenders the world to antigodly powers. If we perceive the Spirit as being active unipurposely in world and church, we rob the incarnation of God of its decisive significance. The Spirit of God has created and sustains this world and all it contains, the Spirit has renewed it through the incarnation; death, and resurrection of Jesus Christ, and the Spirit will bring it to its fulfillment in the new life to come, anticipations of which Christians already enjoy now.

47 Cf. the excellent book by G. W. H. Lampe, God as Spirit. The Bampton Lectures, 1976 (Oxford: Clarendon, 1977), here 179. 